\title{
Incidence of herpes genitalis in Northern Ireland in 1973-83 and herpes simplex types 1 and 2 isolated in $1982-4$
}

\author{
HILARY A LAVERY,* J H CONNOLLY, $\dagger$ AND J D RUSSELL $\dagger$ \\ From the *Department of Genitourinary Medicine and the †Regional Virus Laboratory, Royal Victoria \\ Hospital, Belfast, Northern Ireland
}

SUMMARY During $1973-83$ there was a pronounced rise in the number of new cases of herpes genitalis in Northern Ireland. This study of 127 patients with herpes genitalis shows that $30 \%$ had herpes simplex virus type 1 (HSV 1) and $70 \%$ had herpes simplex virus type 2 (HSV 2) infections. Of 41 sexual contacts who attended, only seven had herpes genitalis (caused in each case by HSV 2); another patient had a history of genital lesions, and one other of oral lesions, but HSV was not isolated from either patient. None of the other sexual contacts had a history of oral or genital infection. Of 31 women with herpes genitalis who consented to undergoing cervical cytology, five had atypical changes (all had primary herpes genitalis). Of these, four were infected with HSV 1 and one with HSV 2.

\section{Introduction}

In Great Britain 3691 new cases of herpes genitalis were reported in $1971(12 \cdot 2 / 100000$ population) and by 1978 this had increased to $9036(28 \cdot 8 / 100000$ population). ${ }^{1}$ The latest provisional figures for 1982 are 14 836. Herpes simplex viruses (HSV) are grouped into types 1 and 2 . HSV 2 predominantly causes lesions below the waist and HSV 1 above. Some reports, however, have indicated that HSV 1 may cause more genital infections than was previously thought.

\section{Patients, materials, and methods}

STUDY POPULATION

We recorded the number of cases of herpes genitalis in Northern Ireland in 1973-83 and studied the incidence of HSV 1 and HSV 2 causing genital lesions in 127 patients attending the genitourinary clinic at this hospital during 1982-84.

\section{SEROLOGY}

We tested paired serum samples from patients with herpes against herpes simplex antigen at a starting dilution of $1 / 10$ using the complement fixation test as

Address for reprints: Dr H A Lavery, Department of Midwifery and Gynaecology, Institute of Clinical Science, The Queen's University of Belfast, Grosvenor Road, Belfast BT12 6BJ, Northern Ireland

Accepted for publication 12 April 1985 described previously2 and the microtitre system. Antigens and antisera were supplied by the Division of Microbiological Reagents and Quality Control, Central Public Health Laboratory, London.

\section{ELECTRON MICROSCOPY}

We scraped the base of herpetic lesions with a disposable scalpel blade and smeared the adhering fluid on a glass slide and allowed it to dry. In the laboratory the material was resuspended in distilled water, transferred to an electron microscope grid, negatively stained with phosphotungstic acid ( $\mathrm{pH} 7)$, and viewed in a Philips 301 electron microscope.

\section{ISOLATION OF VIRUS}

We immersed swabs from herpetic lesions in viral transport medium. In the laboratory the liquid from the swabs was inoculated into human embryonic lung (HELu) cells (Flow 2002, Flow laboratories, Irvine, Scotland) and observed daily for typical cytopathic effect. Cell cultures containing HSV were frozen and thawed, then centrifuged to remove cell debris.

\section{VIRUS TYPING}

(1) Standard strains of HSV 1 and HSV 2 were grown in RK13 cells. The cells were washed, sonically disrupted, mixed with Freund's complete adjuvent, and injected subcutaneously into rabbits. Two further injections were given, one with Freund's incomplete adjuvent subcutaneously after three weeks, and the 
other with virus alone intradermally after a further week. To improve specificity, HSV 1 antiserum was absorbed with disrupted cells containing HSV 2, and HSV 2 antiserum was absorbed with disrupted cells containing HSV 1. The first $53 \mathrm{HSV}$ isolates were typed in a neutralisation test using 100 median tissue culture infectious doses of virus and suitable dilutions of either HSV 1 or $\mathrm{HSV} 2$ rabbit antiserum at $37^{\circ} \mathrm{C}$ for one hour. The mixtures of virus and serum and suitable controls were inoculated into HELu cells and observed daily for cytopathic effect.

(2) The same $53 \mathrm{HSV}$ isolates were typed using restriction enzyme analysis. HSV deoxyribonucleic acid (DNA) labelled with the radioactive isotope of phosphorus of atomic mass $32\left(\mathrm{P}^{32}\right)$ was digested with Bam $\mathrm{H} 1$ and Hind III restriction enzymes, and the fragments were separated and analysed. The work was kindly undertaken by Professor J H Subak-Sharpe, Dr A J Davison, and Ms Jill Southern of the MRC Virology Unit, Insititue of Virology, Glasgow.

(3) Monoclonal antibodies to HSV 1 and HSV 2(SyvaMicrotrak, Maidenhead, England) became available later in this study. Cells containing HSV were scraped off the glass, transferred to a 10 well multitest slide (Flow Laboratories), dried, fixed in acetone for 10 minutes, and then covered in either HSV 1 or HSV 2 monoclonal antibody labelled with fluorescein isothiocyanate. The wells were left for $\mathbf{3 0}$ minutes at $37^{\circ} \mathrm{C}$, washed, mounted in glycerol-saline, and viewed in a fluorescence microscope.

\section{Results}

The figure compares the incidence of herpes genitalis with that of all sexually transmitted diseases (STD) diagnosed in Northern Ireland in 1973-83. The yearly number of cases of herpes genitalis increased from three in 1973 to 72 in 1983, with a peak of 115 in 1981. Herpes genitalis accounted for about $0 \cdot 2 \%$ of all STD in Northern Ireland in 1973 and $1.6 \%$ in 1983. All patients studied in the report published here were white.

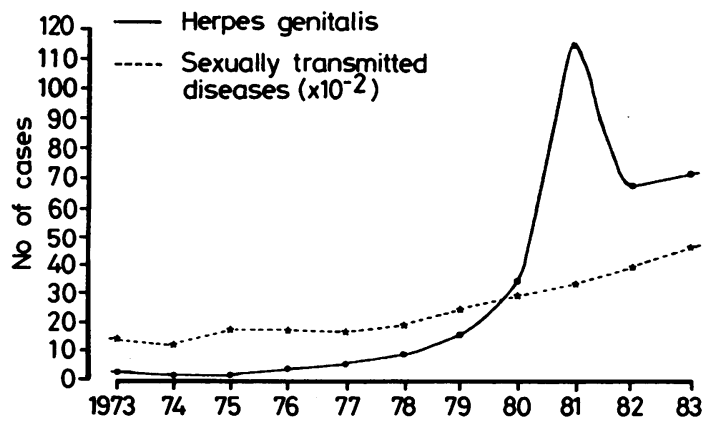

FIGURE Trend of incidence of sexually transmitted diseases compared with herpes genitalis in Northern Ireland 1973-83.
Isolation of the virus was the most sensitive method of diagnosis. Specimens from 84 culture positive patients yielded herpes group viruses in only $28(33 \%)$ by electron microscopy. We obtained paired serum samples from 58 culture positive patients with herpes genitalis. Only eight $(\mathbf{1 4 \%})$ had a fourfold or greater rise in HSV antibody titre, $35(60 \%)$ had static antibody titres, and $15(26 \%)$ showed no antibody at a $1 / 10$ dilution. All the rising titres were associated with patients who claimed that this was their first clinical genital infection with HSV. Static titres were present in all other patients experiencing a first clinical genital infection with HSV for whom serology tests were performed.

TABLE Types of herpes simplex virus (HSV) isolated from patients with genital herpes in 1982-4. Figures in parentheses are percentages of totals.

\begin{tabular}{llll}
\hline Sex & $H S V 1$ & HSV 2 & Totals \\
\hline Men & $19(23)$ & $62(77)$ & 81 \\
Women & $19(41)$ & $27(59)$ & 46 \\
Total & $38(30)$ & $89(70)$ & 127 \\
\hline
\end{tabular}

The table shows the HSV types isolated. The first 53 HSV isolates were typed using absorbed rabbit serum, and the same isolates had their type confirmed by restriction enzyme analysis. The remaining $74 \mathrm{HSV}$ isolates were typed using monoclonal antibodies. Of 127 patients, $38(30 \%)$ were infected with HSV 1 and $89(70 \%)$ with HSV 2 . Of 81 men, $19(23 \cdot 5 \%)$ were infected with HSV 1 and $62(76 \cdot 5 \%)$ with HSV 2 . Of 46 women, $19(41 \cdot 3 \%)$ were infected with HSV 1 and $27(58 \cdot 7 \%)$ were infected with HSV 2.

Of the 127 patients, 43 women and 67 men were experiencing a first clinical genital infection with HSV, and three women and 14 men had secondary herpes genitalis. All cases of recurrent herpes genitalis in men and women were due to HSV 2. ("Secondary" and "recurrent" were both used to describe episodes of herpes genitalis in patients who had previously experienced a first clinical infection with HSV.)

Seventeen men and 16 women, all of whom were experiencing a first clinical genital infection with HSV, had had orogenital sexual contact; 12 patients were infected with HSV 1 and 21 with HSV 2.

Only 30 patients $(24 \%)$ had had more than a single sexual partner in the month before attendance.

Nineteen sexual contacts of men with herpes genitalis due to HSV 2 attended; one had healed genital lesions from which HSV was not isolated, and HSV 2 was isolated from two others. Three sexual contacts of men who had herpes genitalis caused by HSV 1 attended, and none had evidence of oral or genital herpetic infection.

Ten sexual contacts of women with HSV 2 infection 
attended; five were shown to have herpes genitalis caused by HSV 2, and the remaining five had no oral or genital lesions. Nine sexual contacts of women with herpes genitalis caused by HSV 1 attended; only one had a history of oral cold sores, and none had clinical oral or genital herpetic lesions.

Of 31 women who consented to undergoing cervical cytology, five showed cervical atypia; four had herpes genitalis caused by HSV 1 and one had herpes genitalis caused by HSV 2. All five patients were experiencing their first clinical genital infection with HSV.

\section{Discussion}

Herpes genitalis is said to be the most important STD, though all these diseases are increasing in incidence. An upward trend has been seen in the incidence in Northern Ireland, with three new cases being reported in 1973 and 115 in 1981. This compares with the upward trend in other countries; in the United States the number of consultations for genital herpes increased from 29560 in 1966 and 260890 in 19793. It is also in keeping with the increasing number of new cases reported in the United Kingdom, which was 8399 in 1977 and 14836 provisional new cases in 1982.

Herpes genitalis accounts for about $1.6 \%$ of all STD infections in Northern Ireland compared with $13.5 \%$ found by Gardner in his private practice in Texas ${ }^{4}$.

In the study reported here $30 \%$ of all isolates from both men and women contained HSV 1 and 70\% contained HSV 2. This compares with the results from Sheffield, where $61 \cdot 3 \%$ of the isolates contained HSV 1 . In our series $23.5 \%$ of men and $41 \cdot 3 \%$ of women had HSV 1 infections, whereas $76.5 \%$ of men and $58.7 \%$ of women had HSV 2 infections. This compares with $16 \%$ of genital isolates from men and $32 \%$ of those from women in Edinburgh in 1977-9 containing HSV 1,6 and $43 \%$ of female patients in Japan having genital lesions due to HSV ${ }^{17}$. In the study reported here 110 patients with herpes genitalis were experiencing their first clinical genital infection with HSV, and all recurrent cases of herpes genitalis were infected with HSV 2. Typing the isolates is important for prognosis, as Reeves et al showed in a follow up of first episode patients that $14 \%$ of HSV 1 infections recurred, compared with $60 \%$ of HSV 2 infections. 8

In our study of 127 patients, 17 men and 16 women had had orogenital sex, and all of these were experiencing first episodes of HSV; 12 of the 38 patients experiencing first episodes due to HSV 1 , and 21 of the 72 patients experiencing first episodes due to HSV 2 had had orogenital contact. This contrasts with results from Sheffield, where all 14 with primary HSV 1 infection had had orogenital contact compared with four out of eight of those with HSV 2 infection. ${ }^{5}$ In the series reported here only 30 patients $(24 \%)$ had had more than a single sexual partner in the month before attendance; whereas $82 \%(31 / 38)$ of patients from whom HSV 1 was isolated and $74 \%(66 / 89)$ of those from whom HSV 2 was isolated had had a single sexual partner. In Sheffield $74 \%$ of patients from whom HSV 1 was isolated and $42 \%$ with HSV 2 isolates had had a single partner. 5

Virus isolation was the method of choice for diagnosing herpes genitalis, and typing the isolates with monoclonal antibody to HSV 1 or HSV 2 was quick and easy. Electron microscopy of clinical material was positive in only $28(33 \%)$ of 84 culture positive patients. The limitations of electron microscopy are that a large number of virus particles $(>106 / \mathrm{ml})$ are required before even one virus particle can be seen on the microscope screen. The serology test results showed that $74 \%$ (43) of 58 patients had HSV complement fixing antibody in their serum but only $14 \%$ (eight) had a fourfold or greater rise, despite the fact that 50 patients were experiencing their first clinical genital infection with HSV. Previous infection with HSV elsewhere on the body would produce HSV antibody that would not rise with recurrent infection or a primary genital infection with a different type of HSV. Complement fixing HSV antibody was not detected in $26 \%(15 / 58)$ of patients tested. Some of these patients may possibly have had complement fixing HSV antibody detectable at lower dilutions than our starting dilution of $1 / 10$. In addition, HSV neutralising antibody, which was not tested for, tends to persist for longer periods than complement fixing antibody.

Only 41 sexual contacts of 127 patients attended, though the serious nature of the infection and the possible risk to the newborn had been fully explained to all patients. Of these contacts, however, only seven were shown to have herpes genitalis (each caused by HSV 2); another had healed genital lesions and one a history of oral cold sores, but in neither was herpes virus isolated. Thus the infection rate in sexual contacts was lower than expected.

Carcinoma of the cervix has been associated with HSV 2.9 10 Zur Hausen has postulated that the human papillomavirus is implicated in all cases of cervical dysplasia but needs an initiator, such as HSV, to cause malignancy. ${ }^{11}$ In the study published here four of the five patients with cervical atypia had herpes genitalis caused by HSV 1, which emphasises that HSV 1 may also be important in the aetiology of this serious condition.

As HSV 1 is more sensitive to the antiviral activity of chemotherapeutic agents than HSV 2,12 references must be made to the virus serotype when assessing antiviral compounds, as this may influence the results. Treatment is difficult even with the antiherpetic drugs used, with drug resistance being reported and 
recurrences of HSV being common. Long term prophylactic treatment of patients with frequent recurrences is expensive and may also be ineffective.

\section{References}

1. The Academic Department of Genitourinary Medicine of the Middlesex Hospital Medical School, the Communicable Surveillance Centre, and the Communicable Diseases (Scotland) Unit. Sexually transmitted diseases surveillance 1978. Br Med J 1979;ii:1375-6.

2. Bradstreet CMP, Taylor CED. Technique of complementfixation test applicable to the diagnosis of virus diseases. Monthly Bulletin of the Ministry of Health and the Public Health Laboratory Service 1962;21:96-104.

3. Anonymous. Genital herpes infection - United States, 1966-1979. MMWR 1982;31:137-9.

4. Gardner HL. Herpes genitalis: our most important veneral disease. Am J Obstet Gynecol 1979;135:553-4.
5. Peutherer JF, Smith IW, Robertson DHH. Genital infection with herpes simplex virus type 1 . J Infect 1982;4:33-5.

6. Smith IW, Peutherer JF, Robertson DHH. Virological studies in genital herpes. Lancet 1976;ii:1089-90.

7. Kawana T, Kawaguchi T, Sakomoto S. Clinical and virological studies on genital herpes. Lancet 1976;ii:964.

8. Reeves WC, Corey L, Adams HG, Vontver LA, Holmes KK. Risk of recurrence after first episodes of genital herpes: relation to HSV type and antibody response. $N$ Engl $J \mathrm{Med}$ 1981;305:315-9.

9. Royston I Aurelian L. The association of genital herpes with cervical atypia and carcinoma. Am JEpidemiol 1970;91:531-40.

10. Frenkel N, Roizman B, Cassai E, Nahmias A. A DNA fragment of herpes simplex 2 and its transcription in human cervical cancer tissue. Proc Natl Acad Sci USA 1972;69:3734-89.

11. Zur Hausen $\mathbf{H}$. Human genital cancer: synergism between two virus infections or synergism between a virus infection and initiating events? Lancet 1982;ii:1370-2.

12. De Clercq E, Descamps J, Verhelst G, et al. Comparative efficacy of antiherpes drugs against different strains of herpes simplex virus. $J$ Infect Dis 1980;141:563-74. 